\title{
THE CONCEPTION(S) AND THE BIRTH OF ASTIN
}

\author{
A personal view by Gunnar Benktander, presented on the last day \\ of the XXVIIth ASTIN Colloquium in Copenhagen \\ 5 September 1996
}

(reprinted from ABaCusen No. 3/96, with kind permission of the Editor)

Thank you Mr. Chairman.

Dear friends, this has been a very fine Colloquium. For me the greatest thing has however been to meet an old friend for fifty years. Dr. Paul Johansen, now 86 years old. Last time we met was in Zurich in 1980.

In 1946 there was a Nordic Mathematical Congress in Copenhagen. Paul was there, we met Niels Bohr and his brother Harald whom I knew from the wartime when he was a refugee in Stockholm. Today I will deal with events of which only Paul, Teivo Pentikäiinen and myself have some direct experience.

Let us think back on Europe in the years after World War 2, a time when the optimists studied Russian and the pessimists Chinese and where an AngloAmerican orientation was natural. In my country-which is Sweden-and several other countries there was a great admiration of the British, who had been able to resist on their island in the critical year 1940.

Furthermore London was the insurance centre of the world and it was natural for us, who were interested in a future ASTIN, to go there. A disappointment was that insurance managers were against using actuarial talent in the general lines and life actuaries did not like the idea of an ASTIN. One prominent exception was Bobbie Beard, who worked for The Pearl Assurance Company, and later became its General Manager.

An early pilgrim to London was Dr. Paul Johnsen, who met Mr. Beard in 1946. I had that pleasure in 1949.

Things certainly also happened on the continent of Europe: France, Italy, Belgium, Switzerland, Holland and up in the Nordic countries.

As the life actuaries were sceptical of the ASTIN idea, the Permanent Committee of what later became The International Actuarial Association wanted some supervision to be exercised. This task was given to the distinguished Government Actuary in England, Sir George Maddex, the Chris Daykin of those days.

At the actuarial congress in 1954 in Madrid, we-the dissidents-were allowed to meet unofficially for half a day for an exchange of ideas. Research data and statistical results were presented. In Madrid some papers of an ASTIN nature were published.

This was even more the case three years later in New York. 16 ASTIN papers from 8 countries were published. From each of the countries Belgium, Britain, France, Holland and Switzerland one paper, from each of Denmark and Italy two, and from Sweden no fewer than seven papers. 
Why so many papers written by Swedish actuaries? Let me recall that at the beginning of this century Dr. Filip Lundberg presented his Collective Theory of Risk. In his work a central idea was Ruin Theory, the heart of Risk Theory.

Professor Harald Cramer of Stochholm interpreted the works of Dr. Lundberg and further developed the theory. During the thirties he gathered around himself a handful of talented and very brilliant researchers. Some of them became Chief Actuaries.

During the forties a further group of actuaries won respect by analyzing statistics from the general lines, mainly in order to find a realistic basis for the rating in motor, fire, etc.

Let me remind you that in the USA the Casualty Actuarial Society (CAS) existed since 1914. On the European scene the Permanent had agreed on the formation of a provisional ASTIN Committee with the following personalities, namely Mr. Beard, Prof. Franckx, Dr. Johansen, Mr. Monic, their activities to be supervised-as I said before-by Sir George Maddex.

Such was the situation when we prepared to go to New York in the autumn of 1957. A matter of decisive importance was the election of a chairman for ASTIN. Actually there were two prominent candidates and now the drama begins!

The Swedes-based on their above mentioned strength and with the support of the other Nordic countries-believed themselves to be able to determine the outcome of the election of the chairman. Impossible today, certainly.

Paul decided to come to Stockholm. I met him at the Bromma Airport and in my home four of us put relevant questions to him. The other three have passed away. One was Carl Philipson, known for writing papers very difficult to understand. Another was Ingvar Sternberg with his orientation towards statistical facts and his reservation regarding the so called "integral boys". Both served later on the ASTIN Committee. The third one was Carl-Otto Segerdahl who joined the publishing board of the ASTIN Bulletin.

The next step was that Sternberg and myself on behalf of the Swedish actuaries should meet and interview the other candidate in New York. So there were two prominent and distinguished candidates. We ourselves were clearly in favour of Paul and we took care to make our preference known.

And now to the final act of the drama.

Those with an ASTIN interest met on the 16th and 17th of October 1957. I think there were some thirty of us. Unexpectedly the French launched a third candidate a prominent "President et Directeur General"! This was in a way natural as statistical research in the general lines was highly developed in France. Remember that Buonaparte--his original spelling — had started L'Ecole Polytechnique! Several leading managers in France were Polytechniciens. So it was by no way Napoleonic that a third candidate appeared. The voting took place. Sir George counted the votes, put them in his pocket and stated, "Dr. Paul Johansen has been elected with a clear majority"! My interpretation of this was that Paul had received more than $50 \%$ of the votes, in other words, he did not profit from the francophonic split.

Paul became an excellent chairman, even better than we had expected. He could rely upon his great linguistic abilities, his Danish charm and his general insurance knowledge. 
Paul gave 23 years of devoted service to ASTIN before retiring from the Committee in 1981. It has been a great pleasure to me personally-and I know that feeling has been shared by the other actuaries here who have fond memories of Paul from earlier days - to see him back among us here in Copenhagen.

I shall end with a quotation from Paul. In a short sentence he distinguished between life and non-life mathematics: "You only die once — and totally". 